\title{
11
}

\section{Transforming Inequalities and Uncertainty: Gender, Generational and Class Dimensions in the Gende's Longue Durée}

Laura Zimmer-Tamakoshi

\section{Introduction}

Generalisations about patriarchal custom in Papua New Guinea (PNG) have long been challenged by works that investigate the power of women in societies where women participate in local exchange systems and the fulfilment of obligations to exercise control over the distribution of important items of exchange. While many traditions of malefemale relations allow women little voice in political decision-making (see Macintyre, 1998, pp. 212-217), the traditions of the Gende people of Madang Province empower women of all ages and instil stability in systems built on intergenerational and brother-sister cooperation and marital ties between kin-based groups (Zimmer, 1985; Zimmer-Tamakoshi, 1997a; elsewhere in PNG, see Faithorn, 1976; Goodale, 1983; Warry, 1986). Throughout the longue durée of the Gende's pre- and post-European contact history, and in the face of uneven access to education and money, women have tenaciously held onto gender equality. However, new forms 
of economic inequality have transformed local moral economies, given rise to new subjectivities and class relations and driven intergenerational conflict between men.

My anthropological research has always been driven by questions of inequality. I was inspired by anthropologists Louise Morauta and Dawn Ryan, who demonstrated that villages were not the homogenous and mythical 'homeland' or 'ples' that some (including the government) wished for, where migrants were welcomed back regardless of their success or failure in the urban workforce and their remittances and exchange performances (Morauta, 1979, 1981a, 1981b; Ryan, 1968; Morauta \& Ryan, 1982). As part of Jane Goodale's Bryn Mawr 'mafia' and a Philadelphia-area Women and Development Study group, I was schooled in the importance of women and men of all ages in both traditional and changing exchange systems (Zimmer-Tamakoshi \& Dickerson-Putman, 2008; Zimmer-Tamakoshi, 2008; see also Goodale, 1971, 1983; Sexton, 1982, 1986; Weiner, 1976). Hoping to further the study of the impacts of urban migration and inequality on rural and urban communities by bringing gender and generational issues to the foreground, and with Morauta as my in-country sponsor and mentor, I undertook fieldwork in 1982-83 among Gende people living at Yandera village. They were off the beaten track of development projects and had high outmigration rates of both men and women, most of whom were living permanently in town. I was also interested in whether mining projects - as foreign mining companies had been prospecting in the area since the 1960s_-might compound rural inequalities that had already emerged as the result of unequal urban remittances.

My engagements with the Gende have continued over my career. After finishing my dissertation (Zimmer, 1985), I taught at the University of Papua New Guinea for three and a half years and have returned often to work with the Gende (most recently in 2016). When mining took off in the 1990s and 2000s, I undertook consulting projects at the Ramu Nickel site at Kurumbukare (beginning in 1995) and witnessed the aggressive copper exploration undertaken by Marengo Mining near Yandera village and its far-flung impact zone (beginning in 2007). Since 1982, I have studied the impacts of development (or its absence) on both powerful and less powerful Gende men and women in village, town and mining camp settings. Much of my early work focused on how migration and urbanisation have transformed gender relationships. At a time when gender was often equated with women's studies, Jeanette Dickerson-Putman and I explored how development transformed men's lives and how the changed 
situations of men affected women and vice versa (Dickerson-Putman \& Zimmer-Tamakoshi, 1994). As my work has shown, men's success or failure is intersected or imbricated with women's varied situations and choices (e.g. Rosi \& Zimmer-Tamakoshi, 1993; Zimmer-Tamakoshi, 1993a, 1993b, 1996a, 1996b, 1997a, 1997b, 1998).

The Gende have dealt with periods of extreme inequality and uncertainty for countless generations. Centuries ago, when they lived in PNG's interior, they were forced from their lands by tribal warfare. While many Gende sought refuge with nearby allies and in-laws, some younger Gende travelled to the less-populated northern Bismarck mountains and favourably positioned themselves along ancient trade routes. With flexible and egalitarian traditions, young men and women created ties with new neighbours through marriage and trade and, over time, established generational bonds and exchanges with their own offspring. Without the direct support (and control) of elders during the transition, bands of Gende youths, siblings and young couples nonetheless succeeded in making a new place for themselves, a place they eventually populated from the Ramu foothills back up into the tallest mountains in Chimbu territory.

Beginning in 1932, an influx of traders and missionaries and their goods unsettled the Gende's position as middlemen, setting off waves of migration for wage labour in towns and on plantations built by German and Australian colonists. Recent mining developments are generating return mobilities as migrants hope to cash in on jobs and royalties flowing to village people (Zimmer-Tamakoshi, 2012, 2014a, 2016; see also Bainton \& Banks, 2018). 'Big men' who strove to hold society together by promising development and levelling rural-urban inequalities have been replaced by wealthy younger men who are more interested in personal glorification than social cohesion and in dominating their wives than partnering with them. This chapter tracks the emergence of relations of inequality over the long term of Gende history, including the more than three decades of my own research, which has spanned an era in which wage-migration has been supplanted by mining as the dominant form of economic engagement. It focuses particularly on relationships between genders and across generations in an era when Gende society has appeared to fracture and ends with a discussion of whither the Gende moral economy in an era of big mining and its extreme inequalities. ${ }^{1}$

1 See Bainton (this volume) for comparable processes around the Lihir gold mine and Cox (this volume) and Gewertz and Errington (this volume) for complementary discussions of moral economies in Melanesia. 


\section{A Resilient Past and Moral Economy}

According to linguistic evidence and oral history (Aufenanger, 1979; Hughes, 1977; Kituai, n.d.; Z'graggen, 1975; Zimmer, 1985), the Gende once lived in the eastern highlands near what is now the town of Goroka. Fleeing their homeland due to tribal warfare, bands of Gende migrated north over the tall Bismarcks to the sparsely-populated hills and lowlands near the Ramu river (see Figure 1). While many Gende stayed behind and were taken into neighbouring highlands groups, those who ventured into new territory eventually made it their own, making ties with new neighbours through marriage and trade. Soon, clusters of men and women descended from these pioneers made their way back up the Bismarck mountains, following the tracks of Gende traders through rugged terrain and extending their social and political networks to include both the smaller and dispersed Ramu river peoples and the powerful Chimbus on the other side of the Bismarck divide and the Jimi river peoples to the west.

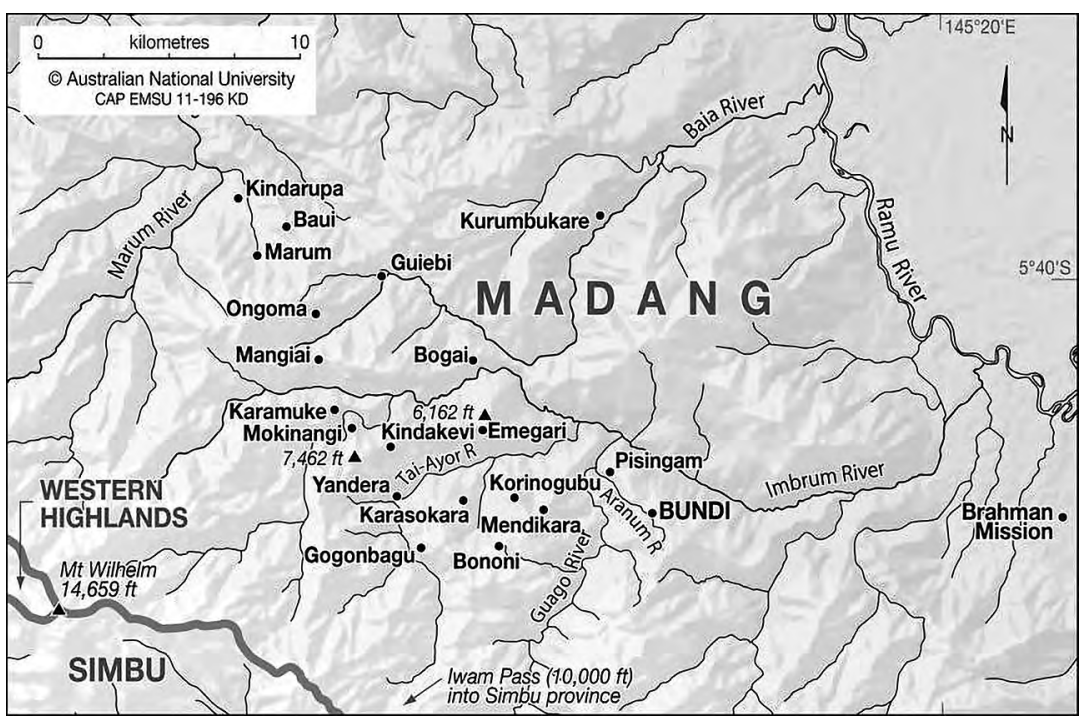

Figure 1: Gende villages are located in a mountainous region of Madang Province that borders Simbu Province.

Source: Education and Multimedia Services, College of Asia and the Pacific, Australian National University. 
The Gende settlers were soon joined by other men and women, who preferred the cooler, less malarial and less snake-infested mountains, where traditional staples like sweet potatoes could be cultivated and pandanus fruit and nuts consumed and traded in the rainy season. By the time I arrived in Yandera village in 1982, six generations of men and women had descended from Bamdi, the eponymous founder of one of the seven sub-clans in Yandera. Bamdi himself was allegedly the descendant of Kabizhi, a Gende and Warakai clansman who had travelled from the Ramu foothills unknown generations before to establish Tundega clan in what became Yandera.

With strategic marriages and exchange relations, Gende men and women fashioned strong links within and between north-south and east-west trade routes. Valuable resources, such as shells from the north coast and stone suitable for axes and arrow points from the highlands, flowed through the hands of the most connected and skilled traders (Hughes, 1977). Women from all the different peoples involved in these regional trade routes travelled back and forth between their places of birth and their husbands' hamlets. Those who were still alive during my visits proudly told me about the stone axes and shells that were included in their brideprices, exchanges that reflected their value and desirability as women who were able and willing to work hard raising pigs and children. During hikes in the higher mountains, several were quick to point out vantage points from which one could see from mountain to sea. The first time, in 1982, we stood on a mountainside not far from the border with Chimbu Province on a clear day and saw the north coast-some 50 miles away. Karkar and Manam islands were visible, as was an ash-laden plume from Manam's active crater. I knew then that women had the same opportunities as men to see the Ramu river plains, coast and paths followed by shell valuables, traders and, later, by white men.

Moving along their migration routes, the Gende practised a system of exchange that encompassed their lives. Reciprocity was at the core of the Gende social contract, and young people were obligated to respect and support the elders who had nurtured them as children and invested in their ritual transition to adulthood and marriage. Flexible enough to accept outsiders as 'children' or 'parents', the system of reciprocity provided a means of judging humanity and a motivation to be 'good'. Gende who were very 'good' were considered 'big' (nambaio); big men and women (wana nambaio and ana nambaio) promoted the wellbeing of their kin groups and settlements by looking after more than their 
immediate family, investing widely in child wealth payments, initiations and marriages. Above all, the generosity of 'big men' and 'big women' was demonstrated through large, coordinated exchange events, called poi nomu (literally 'pig house'). These included competitive gifting and other exchanges timed to coincide that cemented ties with allies, assuaged enemies, showed off young male and female initiates and women's industry and ensured peaceful ancestor-hood for the elderly and the fair distribution of the deceased's rights to land (Zimmer-Tamakoshi, 1996a, 1997a, 1997c, 1998).

Two kinds of rituals, called kwiagi and tupoi, continue to be critical elements in smooth intergenerational and other relations among the Gende. In kwiagi, or death payment parties, the deceased's grown children and their spouses give large quantities of cooked pork and other gifts to pay off the debts of the deceased and to ease the grief of the deceased's relatives. If children fail to give generously in kwiagi, they may lose land rights associated with the deceased and incur ancestral ill will. Those husbands and wives, brothers and sisters, and any others who work to ensure a kwiagis success may earn the status of 'owners' or caretakers of land in their own, or even their spouse's, clan territories. Rather than understanding land ownership as inherited by birth, the Gende consider whoever works the land and pays off their own or the previous owner's debts to be papamama bilong graun (the 'landowner'). This not only allows smaller clans to grow or to be absorbed into other clans, but also may be used as a negotiating tool—as when the first Gende who settled in the Ramu river area used it to convince Ramu and allies to grant them land and hunting rights in the foothills near Kurumbukare and allow them to marry Ramu women.

In addition to taking leading roles in these kwiagi, women could attain considerable power through a women's ritual known as tupoi. Before a woman's marriage, her parents and married elder siblings spent days and nights advising her about her rights and obligations to her own and her future husband's clans, about sex and childbirth and about her intrinsic value as an individual. Such training helped to equip young women to set off for the unknown with their brothers or young husbands. As in many parts of PNG, the husband's family gave pigs and other wealth to the bride's family, binding the families together and transferring some rights over the woman's labour and children from her natal to her affinal kin. However, among Gende, married women were expected to redeem their brideprices through tupoi, a ritual of 'returning the pigs' that granted 
them greater authority in their dealings with family and in-laws. In the past, a recently married husband would help clear gardens for his wife under the watchful eye of his mother; however, the young couple was forbidden to have sex until the bride fulfilled this rite. One can see that this was a useful taboo for all sides in the transaction-the in-laws were assured that their daughter-in-law was not lazy, her parents knew she was respected, and the young couple was ready to take on social adulthood and parenthood. As brideprices have risen and other customs have changed, couples no longer wait to have sex; however, tupoi is still a measure of a woman's status and a doorway to many freedoms. One such freedom is divorce. Another is her right to use any pigs or wealth she gains in the future to her own ends, including investing in others' marriages, children and so on. In doing so, a woman becomes vested in land rights in her own and other clans' territories. Although she may not be a big man walking up and down a line of slaughtered pigs, loudly declaring his generosity and greatness, she has as much (if not more) political influence over who is going to receive that pork. Even today, with great sums of cash in the hands of few men and even fewer women, women raising herds of 10 or more pigs are a force to be reckoned with.

These rituals linked Gende people from the foothills of the Bismarck ranges to the highlands and their Chimbu, Ramu and other allies and affines; however, they did not always prevent violent conflicts. A critical divide among the Gende-which continues to this day over mining and landowner issues - was the alliance of clans spread out in a swath of settlements near present-day Bundi and Emegari and Karasokara villages. Their closest combatants and competitors in the north-south trade route were a large, more or less parallel strip of allied clans composed of people living near Kurumbukare and in the taller mountains.

The Gende's last major conflict began shortly before foreign missionaries arrived in 1932 and within the memories of persons still alive in the early 1980s. The conflict started between Karasokara and Yandera villages. The two had a history of tension, but the fight began prosaically enough. Three Yandera women were insulted by Karasokara suitors who told others that the girls had sex with them so that they might marry rich men. At the time, the boys' elders were seething over the small amount of pork they had received from Yandera exchange partners at a recent pig kill. Conflict erupted when the young women returned their suitors' insults by lifting their skirts and shouting that they would never marry them and that their naked backsides were all the boys would ever see of them. Outraged, 
Karasokara warriors and their Emegari allies drove the outnumbered Yandera villagers from their land. Tundega and Yandima clan members began returning to their lands after the missionaries arrived, but sporadic fighting continued up until World War II over areas of land that had been lost. Resolving the deaths of warriors on both sides was a focus of exchanges between Karasokara and Yandera leaders at Yandera's last poi nomu in 1982. More recent conflicts revolved around mining and land ownership as Yandera sought to cut off affinal ties with Karasokara and their allies.

\section{The Transformation of Regional Economies, Migration and Inequality}

The arrival of the missionaries and government patrols in the $1930 \mathrm{~s}$ sparked massive economic, social and political shifts throughout Gende society. Bringing in large quantities of cowry shells from the coast, the outsiders caused the inflation and rapid collapse of the shell economy and undermined the Gende's role as middlemen. Wage labour changed the balance between elder and younger kinspeople, as younger workers soon had alternative means of accumulating wealth and choosing their own routes to success. Christianity had its own impacts on marriage and other customs. Importantly, engagement with the colonial economy created lasting inequalities across Gende society and between the Gende and their former trading partners, particularly their relationships with the Chimbu, who would soon be wealthier than they.

In 1932, Catholic missionaries travelled to the highlands from the north coast, having heard there were as many people behind the tall Bismarck mountains as there were leaves on a tree. The first actual highlanders they ran into were Gende, who had long before resettled on the Bismarcks' northern flanks in Guiebi village. A man from Utu, a small Sepu village near the Ramu river, showed Father Alfons Schaefer and Brother Anthony Bass the steep path up to Guiebi. While Utu undoubtedly had ties with the Gende through trade and possibly marriage, he feigned fear of the Gende long enough to convince Schaefer to give him a pair of his pants. When they finally came across a garden in which women were working, the Sepu man discreetly disappeared, leaving the German missionaries and their carriers on their own. The women were startled, cried out and were soon joined by their menfolk. 
While some Gende were frightened and called the white-skinned men 'ghosts', most were excited by the cowry shells the newcomers used to pay for things. Traditionally, a pig traded to the Gende by their Chimbu trading partners would fetch a string of cowry shells the length of the pig. Through helping the missionaries build missions at Guiebi and then Bundi, where they also built an airstrip, it was not long before many ordinary Gende-women and men-had more cowry shells than most big men. Big men found themselves in the embarrassing position of having to work alongside lesser men and children to maintain their status as leaders and middlemen in the north-south trade route.

Chimbu trading partners soon wondered about the explosion of Gende wealth. In early 1933, a prominent Chimbu leader, Kavagl, visited the mission at Bundi (his Gende wife's home village) with his wife and hundreds of his followers on a trading trip to buy brides and attend a large kaima (or singsing) festival hosted by his Gende in-laws. Seeing their apparent prosperity, Kavagl invited Father Schaefer to visit his people in the highlands. Initially, Schaefer hesitated; however, in November, after receiving news of the Leahy brothers' expedition into the highland valleys, he took up Kavagl's offer and started a mission in Mingende. Other Catholic missionaries followed, making their way into the Wahgi Valley and leaving a string of airstrips and missions in their wake.

The missionaries and colonial government were keen to develop the densely populated central valleys and airlifted tons of shells and other goods into the highlands. The effects on the Gende were significanttheir middleman role was eliminated and massive inflation occurred in the local economy. Marriages and other ties based on worthless shells collapsed, and reputations were ruined.

Finding themselves suddenly massively disadvantaged in relation to their highland allies, the Gende began to forge new translocal connections through the mission, Allied forces, European commercial interests and the colonial government. Father Heinrich Aufenanger, who had replaced Father Schaefer in 1934, sent catechists to Gende villages to promote the learning of Tok Pisin and Christian principles. Soon, Gende catechists were travelling far and wide. During World War II, Gende men were carriers and orderlies for Allied forces fighting the Japanese in the Ramu valley. After the war, men headed south to the new towns of Goroka, Kundiawa and Mt Hagen, where they worked as cooks and servants or joined construction gangs, building the airstrip in Goroka and other 
developments. Others worked on coastal plantations as far away as Kavieng and Port Moresby, at the Wau-Bulolo goldfields or as carriers and native police on government patrols into uncontrolled areas of the highlands. When migrants came home and distributed imported goods, more Gende left home, including women. While women had few job opportunities other than as 'house girls' (haus meri), they cooked and washed clothes for their husbands and younger clan brothers, tended small gardens and raised a pig or two, providing stability and a certain independence among the younger generation. Some couples became permanent urban dwellers, raising families and sending them to urban schools.

By the mid-1950s, migration became a regular part of young men's lives as parents expected cash as part of their daughters' brideprices. Older villagers and wives who stayed behind often suffered from a lack of male labour and unfulfilled exchange obligations, because not everyone was successful in finding a job, wanted to return home or was welcome if they did. Coffee plantations were opening in the central highland valleys, and patrol posts were becoming towns in need of carpenters and other labour. Roads were built in other parts of the country, linking some villagers to the coffee market-but not the Gende.

In 1958, Father Mike Morrison opened the first English-speaking school in the highlands at Bundi. Those Gende who helped build it envisioned a positive shift in Gende fortunes, with future migrants making more money and sharing it with their extended families; conversely, the church saw it as a way of creating a class of educated Catholics living in nuclear households and practising Western ways. The first class had 36 boys. Later, at Morrison's insistence, 20 girls were admitted. English was taught to prepare children for higher education in business, clerical, managerial and other skills needed in an expanding urban job market. As the school grew, teachers were brought in from Australia. In 1965, a first graduating class of 30 students (mostly male) was flown to Madang to continue their education. While fewer girls went on to higher education, those who did used their education to promote their independence and status, some helping extended families and others less so. Ultimately, school and education were major sources of inequality among Gende society.

The years leading up to national independence in 1975 were a time of both promise and concern for Gende villagers. There were roads to build, coffee to plant, local councils to elect and national politics to understand. More cash flowed into the exchange system as individual growers carried 
coffee to markets over the mountains, mining companies explored for copper near Yandera village and nickel and cobalt at Kurumbukare, beginning in the 1960s, and some of the first graduates from the school at Bundi became doctors, teachers, secretaries, bank clerks and government workers. Unfortunately, individual remittances and earnings were vastly unequal; mining companies were not finding viable deposits and their high turnover added uncertainty to the economy. Further, roads were difficult to build in the steep environment and had little support from the government; wealthier Chimbu neighbours, with better roads connecting them to coffee markets, drew many Gende brides while escalating prices for Chimbu brides made them unaffordable for most Gende bachelors and their families (Zimmer-Tamakoshi, 1993a).

\section{Intergenerational Conflict and Troubled Masculinities}

When I arrived in Yandera, 50 years after the missionaries, my census showed that only one of 57 men between the ages of 18 and 24 and only 37 of 67 between the ages of 25 and 34 were married. Most older men had married in their mid-20s. The fallen middlemen of the 1930s had been unable to help their sons contract marriages, and some also lost their own wives. Unmarried men felt great shame over their inability to attract marriage partners to achieve social adulthood (Zimmer, 1984). Bachelors responded to the challenges facing them by trying their luck in town. Parents and other family members complicated their situations by investing in migrants or returnees who had more money, granting them land rights and brideprice support in return for the fulfilment of exchange obligations that their sons were not meeting. Traditions intended to provide stability were being used by the older generation to balance their own obligations while also placing their sons in liminal positions (Zimmer, 1990a). Parents justified their choices as temporary, hoping children would strike it rich and regain land rights during kwiagi; however, they rarely did.

One migrant who benefited from intergenerational conflicts with a judicious return to Yandera was Ruge Angiva. I have detailed the lives of Ruge and his family in many publications (Zimmer-Tamakoshi, 1996a, 1997b, 2016); these are instructive of the different paths Gende have taken to navigate the possibilities and trials of social and political change. 
They shatter any illusion that Gende society is one integral, undivided community. As the stories of Ruge's family illustrate, local power dynamics shift as individuals and coalitions manage their relationships through exchange and other means. Anything that disturbs parts of the webs of exchange also disturbs or provides opportunities for others.

When the missionaries came, Ruge's father (Angiva) became one of their helpers, establishing a Tok Pisin school and church in Yandera. He also served as village Tultul (counsellor), assisting Australian officers in getting Gende to live in compact villages, where they were enumerated and taxed and where Western medicine and other services were administered. Spurning polygyny and other traditions, Angiva worked hard to help his community benefit from the presence of outsiders, believing Christianity and modernity were the way to go. Although he was poorly paid, he shared what little he earned, and his wife Amokai worked hard in her gardens and raised many pigs. For these reasons, many considered him a good man and named their sons after him. Even so, when he died in his early fifties, around 1960, he left many traditional exchange obligations unfulfilled and his only son landless (Zimmer-Tamakoshi, 2016, pp. 255-256).

Ruge and his sisters were among the first Gende to attend the Tok Pisin school established by their father. Learning Tok Pisin made it easier to interact with the missionaries and colonial officials, in addition to finding work in towns and elsewhere. Believing a catechist that initiation was heathen, Ruge ran away to Kundiawa, a town in the eastern highlands, where he worked for years as a male servant (haus boi) for Australians. In the home of one masta, Ruge cautiously drank alcohol with the young Australian while shrewdly observing his behaviour for insights into the waitman's ways. When Ruge returned to Yandera for a visit, his unclesannoyed with their brother and wanting to groom their oldest nephew to be a leader of his own generation and a generous supporter of theirscomplained that he had not completed his initiation, arguing that this would bring ill fortune to him. Not believing them but wanting to marry, Ruge agreed on an abbreviated initiation. His uncles and his mother then negotiated a brideprice for a woman from Yandera's other clan. Rosa, following tradition, stayed with Ruge's mother to raise pigs for her tupoi obligation to her in-laws. Leaving it to others to clear gardens for Rosa, Ruge went off to Goroka in the late 1950s with another girl, Elizabeth, who snuck away from her home village (Karasokara) to be with him. Ruge worked as a cook and Elizabeth as a house girl for an Australian family. 
Saving AUD 70, Ruge helped pay brideprice for Elizabeth, making him one of the first Gende to contribute cash to his wife's brideprice. In the seven years they lived in Goroka, Ruge and Elizabeth hosted many of Ruge's younger cousins that were seeking jobs. For a time, they were joined by Rosa, who posed as Elizabeth's sister because polygyny was frowned upon by their employers. Soon after, in 1958, Elizabeth bore a daughter-Betty. When Rosa, too, became pregnant, she returned to Yandera and began raising pigs for an expected child wealth payment to her clan (Zimmer-Tamakoshi, 2016, pp. 256-247).

Realising that there was little future for him in town and encouraged by his uncles to work towards becoming a big man with knowledge of white men's ways, Ruge returned to Yandera. His father had forfeited land rights in helping the church; however, Ruge's uncles invested plentiful land - and their wives and his mother invested plentiful pigs - to support Ruge's ambitions. His family grew to include three wives and 15 children. Elizabeth, having seen the benefits of education, registered her oldest daughters at the boarding school in Bundi in the early 1960s. By 1982, all their hard work and planning had paid off. Cash from Elizabeth's oldest daughter Betty (then an Air Niugini stewardess) and Elizabeth's trade store, along with the many pigs and other contributions from his wives, mothers and aunts, supported a large poi nomu that validated Ruge's big man status.

Though much of Ruge's wealth was in pigs and his extended social network, access to cash was changing traditional pathways to success and who was winning. Another man to achieve big man status in the 1982 poi nomu was Peter Tuma, the young local camp manager for the mining company developing the Yandera prospect. He had only one wife, but was supported by the many villagers who had received school fees for their children and other cash payments from him over the years. They supplied him with the pigs and pork that he distributed at the poi nomu. Noteworthy among the seven big men in Yandera was Lapun ('old man') Gene, the reigning and oldest big man in Yandera and one of the most influential in Gende society. Gene owned much of the land in which copper deposits lay and his adult sons, many with lucrative jobs in town, had also held well-paid jobs with the mining companies that came and went. Together, Gene and his sons timed Gene's 'retirement party' to coincide with the poi nomu. A big man for decades, Gene staged his own final death payment exchange, a kwiagi at which all his debts and obligations were paid off by him, his wives and his sons and their wives, resulting in his land rights in Yandera 
turning over to the younger generation. After the event, Gene and his wives intentionally moved to one wife's home village near Kurumbukare where they continued investing in land rights there, betting that one day prospectors (and they and their children) would strike it rich.

Sometimes, such attempts to amass or even just acquire land rights result in violence. In 1982, a cousin of Ruge who had returned to Yandera from town argued furiously with his uncles and Ruge about rights to his father's land. When this cousin's father died years before, Ruge paid most of his kwiagi debts and became the rightful owner of the land. Although Ruge allowed his cousin's wife to use some of the land, his cousin's anger continued unabated. In 1990, he assaulted Ruge so badly that he died. Most of the time, such violence was held in check through the maintenance of a large network of ties that would ensure some access to land and other resources (Zimmer, 1990b). An inventive card-playing system and other means of spreading wealth around to an extent also helped (see Zimmer, 1986, 1987) as did the realisation that, while the mining company was creating temporary inequalities, there was nothing certain about its long-term success.

Rising inequality affected women differently to men. The escalation in brideprice meant that they had to raise more pigs to repay their own brideprices and to help sons marry. Some older village women even took up part-time work at a spice company near Bundi; however, they quit and brought down the whole operation when they realised that younger women who had the time to sort cardamom into different grades all day were being paid higher wages and, thus, contributing to brideprice inflation for everyone (Zimmer-Tamakoshi, 1996b; see also Filer, 1985). However, women always had access to land and were not ashamed of renting and working on others' land in the way that men tended to be. While men resented women for having it 'easier', physical violence against Gende women was uncommon in both village and town. Married women at Okiufa and other urban settlements, who could only raise a pig or two on the land they rented from local landowners, nonetheless led respectable lives managing their husbands' modest incomes, scrimping and saving, keeping husbands away from temptations and alcohol on paydays, investing in children's education and maintaining exchange ties with villagers in expectation of future mining and other developments. Paradoxically, perhaps, women married to more prosperous townsmen or working in two-income professional families struggled to manage extended households of in-laws and others with little support from 
husbands and other male relatives (Zimmer, 1990a; Zimmer-Tamakoshi, 1993a, 1993b, 1998). Yet, even women who were abused by their urban husbands could escape by returning to the village and raising pigs to pay back brideprices. In 1983, I witnessed a young woman quietly face down her angry brother who had expected to use her brideprice from a prosperous townsmen to acquire his own bride. The woman had the moral support of many at Yandera's crowded village market in addition to her parents, who had already returned the brideprice to their daughter's in-laws to reduce conflict. The young woman planned to marry a returned migrant, who had not prospered in town but was willing to work with his wife-to-be to raise many pigs for her parents and brother. The angry brother was virtually booed off the school playing field where the market was held.

Even if, in this context, women tend not to experience shame as intensely as men, emerging inequalities among women are also evident even in the same family. Ruge's oldest daughter, Betty, intentionally avoided being controlled by in-laws by marrying Australian men and building a business empire (Zimmer-Tamakoshi, 1993b, 1996a). Not long after her father's poi namu, she set up a coffee-buying business in Yandera village with the intention of 'helping' her kin (see Cox, this volume); however, this venture was marred by resentment and competition. She continued with other enterprises: a farm to provision urban markets along the Highlands Highway (and, later, two mining operations), PNG's first trout farm and a successful tourist business and lodge for people wanting to hike to the top of the nation's highest mountain. Each of these endeavours required a large labour force, which she drew from her extended family in Yandera. While Betty prides herself in being the 'mother of all' and the hardest working member of the crew (which is true), she enjoys privileges such as international travel and a large modern house that her siblings and relatives do not. Unsurprisingly, her enterprises were targeted by dissidents in the area who destroyed government vehicles in addition to her trout farm.

Although less privileged women undoubtedly resent the privilege of their middle-class or elite sisters, even poor women retain a public role in a way that men who are unsuccessful in the formal economy do not. While older women can still earn respect raising gardens and pigs and helping their children and grandchildren, older men have receded from the public eye-hiding in their homes after helping their wives in the gardens, selling buai in the marketplaces or playing cards along the side of the road. 


\section{Broken Promises and the Ushering in of New Power Dynamics during the Extraction Boom}

The intergenerational inequality that emerged in force with the bachelorisation of Gende society in the 1970s and 1980s made younger men angry with their elders (particularly fathers) and resentful towards younger women who they perceived as having certain advantages. Gende power dynamics were again transformed by the resurgence of mining prospecting and mining projects in the mid-1990s and afterwards. The social and economic trends since that time threaten to fracture Gende society and identity permanently: leaving 'the boys' and the equivalent of some 'good old boys' in charge, sending a traditional older generation to their graves (or hiding in their garden houses), undermining women's equality with men and intensifying inequality, class relations and different subjectivities such that the once-egalitarian Gende society would be a thing of the past. ${ }^{2}$ Earning high salaries, younger men are able to challenge senior men's control of land through ancestral gerrymandering and to pay their own brideprices. While many younger women have sought status through paid employment or raising more pigs to fulfil tupoi, others forgo marriage or escape through divorce and remarriage or return home to work with their families and less prosperous brothers. Gende families are fragmenting as some members try to keep significantly higher salaries for themselves; Gende society itself is fragmenting as those who have a mine in their backyard are closing off social relations with those who do not.

In 1982, Ruge touted himself as 'the last big man'-a prescient assertion. The poi nomu that drew hundreds of exchange partners from towns throughout PNG, every Gende village and bordering Ramu and Simbu villages was one of the last. The crisis that bachelors faced, in addition to the opportunities education and capitalism were offering some young men, was encouraging a generational shift, one that was obvious at the 1982 poi nomu (see Zimmer, 1985). Alienated migrants who had turned to petty crime (raskolism) in town came home to prey on those who had rejected them, and prosperous townsmen spent more time conferring with one another on what should be done to kickstart development than with

2 I have written about these transformations in scholarly articles (e.g. Zimmer-Tamakoshi, 1997c, 2001, 2006, 2007, 2012, 2014a, 2014b, 2016, 2018) and in reports for Highlands Gold/Pacific (1995, 2000) and Marengo Mining (2007, 2008a, 2008b, 2009, 2010a, 2010b, 2011a-c, 2012, 2014). 
Ruge and other big men. Further, the shame, frustration and anger of former migrants who felt cheated by older relatives simmered and boiled over as others monopolised the interest of potential brides and investors.

Several migrants who had returned to Yandera to participate in the poi nomu organised what they called the 'Bundi Strike'. Challenging local big men's authority, the strike's leaders demanded that government leaders meet them at the district station at Bundi to explain what had happened to funds set aside for a road in the provincial budget. One organiser, a former government worker, wanted to help the Gende develop a stronger stance in relation to the government and mining companies. He saw big men and the older generation as uneducated and locked in the past, worried more about status and competition than the futures of younger generations. Early on the morning of 28 March 1983, a plane carrying invited national and provincial government officials landed on the Bundi airstrip. Within minutes, several thousand Gende, many armed with axes, bows and arrows, surrounded the delegation and prevented the plane from taking off. The organisers delivered a list of grievances and demands. Foremost was the request for funds to complete the road to connect with both Madang and the Highlands Highway. Demonstrators challenged the officials to treat them like 'men' or face the consequences, which included the Gende joining Simbu Province. Having disbanded the local government council and posted sentries at the district headquarters to prevent police interference, the strikers' threats were taken seriously, and the 'disbanded' Gende Council—many of whom were on the airstrip-received promises for future support in addition to cheques in the amount of PGK 25,000 (worth approximately USD 37,500 in 1983), to be used for the Bundi school and to finish part of the road between Bundi and Yandera.

The strike's organisers claimed that they cared about village society; however, very few established leaders were impressed. Ruge refused to be part of the strike, brushing it off as 'a young man's thing' and a way of promoting their own interests. Several of the organisers were already absentee landowners who were benefiting from their less fortunate brothers- and sisters-in-laws, who paid rent for the use of the land in pigs. The local catechist and the manager of the Yandera mining camp also declined to participate, arguing that the church and the mining company would solve the Gende's problems. 
However, they did not. Not the government. Not the church. Not the mining companies. Not even big men like Ruge who worked hard to build extended networks of exchange partners who one day would find marriage partners for his many young sons and their cousins, should he be unable to do so. The promising prospecting initiated by the mining company, which coincided with my departure from Yandera in May 1983, fizzled and it was the middle of the 1990s before the Ramu prospect took off, sparking a whirlwind of divestment in what were thought of as inconvenient exchange relations and investing in relations that the investors hoped would place them in more favourable positions to receive benefits from the extraction industry.

In a 1995 landowners survey at the Ramu Nickel project (Kurumbukare), I found Gende families moving into the sparsely-populated area, contesting the same land blocks with conflicting origin stories. Some Gende, who I had interviewed long before for my 1982 census of Yandera village, claimed new clan identities, one boldly telling me that his wife was a member of a Yandera clan, not him, and that I had got it all wrong. It was obvious that genealogies were futile proof of land ownership. People were using kwiagi ceremony to establish new or reverse ancestral ties. Nightly card games and kwiagi fuelled what I came to term 'ancestral gerrymandering' (Zimmer-Tamakoshi, 1997c, 2001, 2006, 2007). During the day, people I had already interviewed would come to me and say 'I forgot to tell you', before changing their stories. Deals were made, and outsiders were buying their way into others' genealogies. I experienced hostility whenever I questioned these revised versions.

When I returned to the Ramu Nickel project in 2000, women and their unmarried sons confronted me. They were angry because the company and leaders of landowner groups had falsely claimed that I had listed only male heads of household as rightful 'landowners' in my 1995 census, omitting sisters, widows, wives and unmarried sons. The man who was representing Gende to Ramu Nickel, David Tigabu, was the son of a man who had preposterously claimed the whole of Kurumbukare as his own when I interviewed him in Port Moresby in 1995-a time when both father and son were personae non gratae at the proposed mine site. In both 1995 and 2000, and during later meetings with the Chinese company (MCC) that would eventually develop the Ramu Nickel project, I stressed that no single Gende could afford to control the entirety or even major portions of the mine site through kwiagi investments. 
Shortly after my 2000 visit, MCC had negotiated to operationalise production; by 2005, local positions at the mine were being filled by Gende migrants returning to reap the benefits of having sent home remittances for many years (see Zimmer-Tamakoshi, 2014a). In 2007, I began a multi-year census/survey of over 20 Gende and non-Gende villages to be affected by the development of the copper project at Yandera, a pipeline and coastal depot. ${ }^{3}$ The Australian company Marengo Mining acquired the prospect in 2005 and quickly began digging new holes and expanding their area of exploration. From 2007 through 2012 and 2014, my team and I collected extensive data on all households in the region, including those of migrants who returned from elsewhere to be counted in Gende country, who were interviewed in town or whose information was provided by their village kin. ${ }^{4}$ Many of the migrants were living (some working) at the Ramu Nickel project. Therefore, while the focus was on the impact of the proposed Yandera project, I learned a lot about events in the Kurumbukare area.

Perhaps the most important finding was that the Gende were committed to mining, despite its negative impacts on the environment and society, because it was ending bachelorisation in Yandera and nearby villages. Men were able to obtain jobs with salaries ranging between PGK 5,000 and tens of thousands of kina; thus, they were able to marry. Returned migrants with special skills drew the highest salaries, allowing some to have more than one wife and play at being 'big shots' (Martin, 2013). Real big men were a thing of the past, much like large pig feasts and networking with the entire tribe. Unsurprisingly, gambling with company employees was rampant and aggressive, unlike the more sociable and 'good' gambling that still occurs in villages farther away from Yandera and among close kin in garden settlements (Zimmer-Tamakoshi, 2014b, 2016; see also Pickles, 2019). To protect their workers from all-night card games, supervisors at the Yandera project built worker accommodation and camps that are off-limits to anyone not working for the company.

3 The aims of the surveys went far beyond those of the work contracted at Ramu Nickel. The interview schedule I constructed covered many areas, including kinship relations and clan affiliations, work histories, income sources, participation in traditional exchanges such as tupoi, education and more. The interview took approximately three hours to complete. Land tenure and measurements were carried out by a separate team.

4 My team was composed of university-educated Papua New Guineans who had worked with anthropologist Nancy Sullivan on other projects. We received logistical help from Gende working for Marengo and others I had worked with over the years. Many of my findings are discussed in recent publications and presentations (see Zimmer-Tamakoshi, 2012, 2014a, 2014b, 2016, 2018). 
One surprisingly happy segment of Gende society-to me, at least-was the merry widows of Yandera (see Zimmer-Tamakoshi, 2012), some of whom had been married to former big men. They are happy that their sons can now help pay higher brideprices and help pay off their fathers' kwiagi, thereby cementing land rights for both mothers and sons. However, in general, young men's windfall and new independence come at a heavy price. Young men are paying their own brideprice; therefore, they are no longer indebted to either the parents of their wives or their own families, and they may be more likely to treat their wives as their own personal property (Zimmer-Tamakoshi, 2016, p. 262).

Younger wives were less happy about having to raise large pig herds to achieve tupoi and, in some cases, deal with domestic conflict involving co-wives. Nevertheless, census data showed just how hard even women who had grown up in town were willing to work, raising five, six, even 10 pigs at a time to redeem their brideprices and invest in other exchanges, or to sell to wealthier villagers for prices as high as PGK 1,000. Very few women have enviable positions working for the mining companies and, from time to time, there were spats over who had the 'right' to do so. One young woman who returned from town as a fully qualified secretary was driven out of Yandera in less than a week by older women with lesser qualifications who felt that, having lived in Yandera all or most of their lives, they deserved the job more than the young woman did. Those women who fit quite easily back into the village had helped their husbands keep up with exchange relations while they lived in town before coming back to work at the Yandera project (or at Ramu Nickel).

An alarming side effect of mining prosperity was the dissolution of many Gende marriages_-Gende people living near mining projects had begun divorcing distant spouses and remarrying closer to home. The primary motive was to narrow ties, so that future royalties and other benefits did not disperse among distant in-laws. However, this was a risky strategy. When several of the new prospects drilled near Yandera turned out to be duds, in areas where villagers from Snopass and Karasokara villages had long intermarried with Chimbu partners, suddenly brothers had to rely on old ties with their sisters' Chimbu husbands to raise cash crops (coffee) on their in-laws' land or return to town in search of work. Some Gende men, who had attracted Chimbu and Gende wives due to the possibility of striking it rich, lost their wives because they and their parents could not or could no longer front or promise the brideprices. 


\section{'The Boys' and the Generational Split}

This section focuses on the individuals benefiting most by the presence of mining - the former bachelors and younger men working at Ramu Nickel and at Yandera (who head most of the Landowner Associations) and a few older men rich enough to wield considerable influence in the local politics of mining - and presents examples of just how much the Gende's moral economy has shifted due to mining's daunting intrusion into Gende society. 'The Boys' or Gende mavi ('wild dogs'), as they often call themselves, make it clear in person, email and a variety of Facebook groups that they base their hopes for the future on mining and that no one (including the anthropologist) is to obstruct their goals with inconvenient facts. These facts include mining's destructive and unsustainable nature, the ongoing lack of reliable roads, decent health care and schools in most villages and settlements and the exclusion of many Gende, who are unable to achieve political influence through exchange and who can no longer rely on bygone egalitarian expectations.

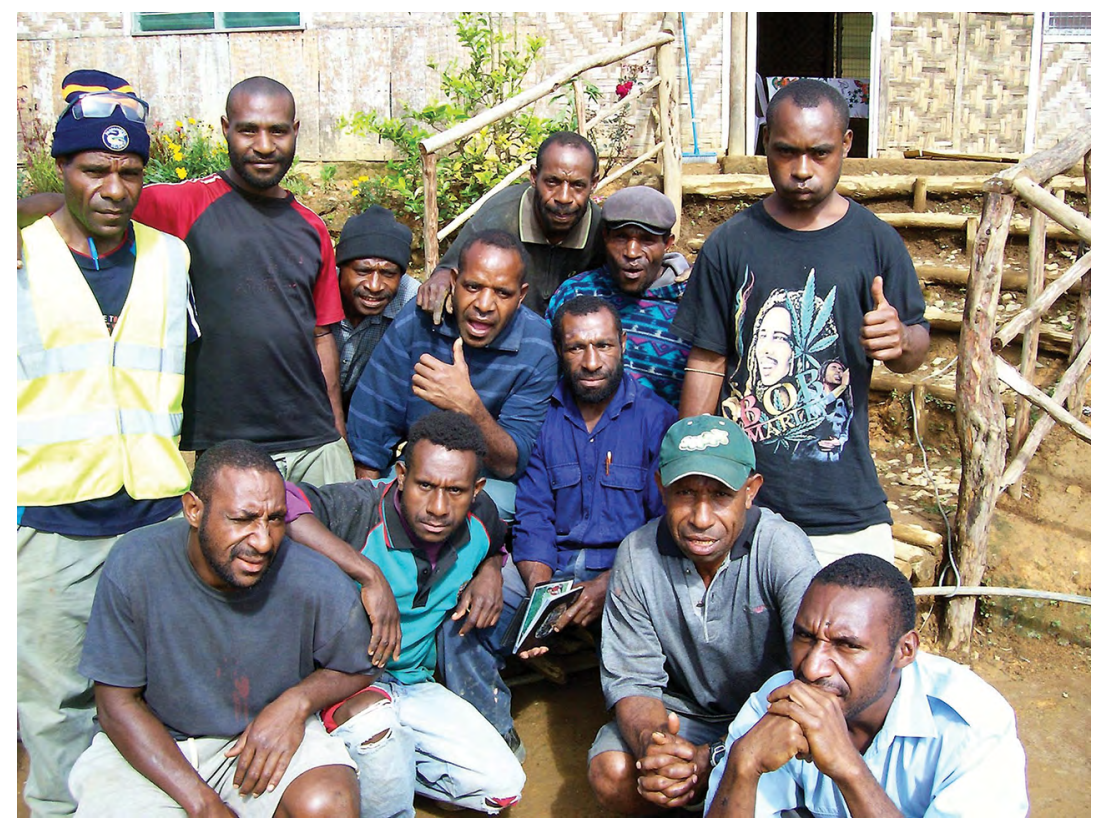

Figure 2: 'The Boys', Yandera Mining Camp (2007).

Source: Photo by Laura Zimmer-Tamakoshi. 
The obvious generational split is unnerving, as is evidence of growing gender inequality and difference between haves and have-nots. Boys with jobs that make PGK 5,000, PGK 6,000 and up to PGK 30,000 or more per annum are using kwiagi and other exchanges to become big landowners, leaving others earning PGK 250 or less a year landless. The Boys, an expression harking back to traditional male initiations where youths grouped together for years in activities in the forest to become men, are now supporting one another more than anyone else.

In the past, initiates hunted wild animals, ate the meat and shared valuable skins and feathers with parents and others who would help them with brideprices. Today, Boys of 20, 30 and, sometimes, 40 years of age are now turning their backs on older men, resenting their handling of development in the past (see also Gewertz \& Errington, this volume). Before and after the Ramu Nickel census, for example, many men vying to be included as 'landowners' left their wives and unmarried sons to tend gardens hacked from the rainforest while they met up in town and spent any money they received (or expected) as landowners to participate in kwiagis, drink beer and even establish second marriages (as opposed to helping their sons acquire wives). The young men and their mothers were used as placeholders. Less of this happened in association with census work conducted at Yandera, because family ancestries and land rights were better known; however, deals were being made, and younger men with money were more in control of those deals.

The phenomenon of young males increasingly bonding with one another has been noted in other mining contexts (see Bainton, 2008). Among the Gende, young men who benefit most from mining favour dealings, compatible with ongoing market participation (see Zimmer-Tamakoshi, 2016), spurn the society-wide networking of their elders as an ineffective use of resources. One such deal occurred during an infamous sex party in Kundiawa. Six or so Boys from Yandera, who were in their 40s, paid thousands of kina for hotel rooms, alcohol and prostitutes, outspending each other over a month, before deciding among themselves who would take on the leadership of the landowner association. This act of conspicuous consumption, reminiscent of national politicians, had regrettable consequences. One contestant for leadership was Ruge's son, a local schoolteacher, who spent his entire superannuation (retirement) savings but did not win the position. The winner of the landowner association leadership role held a well-paid management job at the Yandera mine site. 
He contracted AIDs and died a few years later. The wives of both men were unhappy about their husbands' use of money but had little or no influence over their decisions.

Not long after the sex party incident, the Gende millionaire, security firm owner and then member of parliament, Peter Yama, bought his way into Ruge's clan through his son, the ex-teacher who was desperately in need of cash. Yama already had many financial deals and land claims with Ramu Nickel. When Marengo extended its area of interest beyond Yandera and began prospecting in the area of Yama's father's people, Yama sent two young men to give me his census data in the village of Snopass. When the new prospect did not pan out, Yama claimed that he had 'ancestral' ties to the land in Yandera. Ruge's son was the ideal dupe. Inconveniently for Yama, I knew (and he knew)—from the fieldwork and censuses carried out over the years in Yandera, Snopass and other Gende villages- that he had gerrymandered his way into Yandera at the expense of others less wealthy than he. Several years later, in 2014, Yama's sons menaced me and my female Gende assistant at the Madang Resort Hotel. It was only through subterfuge that I managed to get both of us safely out of Madang.

The 2014 incident was not the first time that my research had become politically inconvenient. In 2007, in a meeting with Ramu Nickel senior management, I was asked 'how do you verify Gende landowners' claims?' When I explained that traditional kwiagi exchanges were being used by wealthier Gende to become members of landowning groups, I was abruptly dismissed. This was inconvenient and threatening knowledge. They were not interested in understanding Gende culture or mining's impact on Everyman (or Woman), and they definitely did not like the idea of flexible kin relations. However, The Boys had a fervent interest in simplifying that process for them. As far back as 1995, it was obvious that The Boys and other powerful players did not want the process of ancestral gerrymandering advertised or explained in too much detail. That week, in 2007, as I was preparing to go to Yandera, and just after my discussion with Ramu Nickel management, young Gende associated with Yama confronted me over a chapter I had written on ancestral gerrymandering at Ramu Nickel (Zimmer-Tamakoshi, 2001), claiming that it was false and that I should retract it. They had accessed the article online. I was being tracked - the perils of long-term research and knowing too much! What is inconvenient for me, however, is more troublesome for Gende who might disagree with Yama_-now Governor of Madang — and others like him who wish to dominate the directions development is taking, for their own enrichment. 


\section{Whither the Gende's Moral Economy?}

Can the Gende's aptitude for resilience and egalitarian practices continue to temper capitalism's onslaught? Alternatively, will toxic inequality and deepening capitalist-oriented subjectivities among some Gende create an unequal class system? Or, has this already occurred? As I have shown, the inequalities among Gende individuals and families are significant. At the same time, the future of mining revenues and mining projects is uncertain. Gende have dealt with uncertainty over the generations by utilising egalitarian practices. However, contemporary uncertainty may lead to a deepening of class interests, another period of ancestral gerrymandering or a return to older forms of egalitarianism. Just as nationbuilders and policy-makers of the past mistakenly assumed that a village necessarily takes care of its own, regardless of their successes or failures in town, it would be a mistake to summarise the Gende's story here and not continue to watch the various trajectories of big and small players.

While villagers may continue raising pigs and sweet potatoes and practising partial customs, there exist deep differences among them in terms of access to mining and other revenue and radical demands on their land and other resources that make egalitarianism difficult if not impossible. While the current existence (and future) of many Gende is grim when contrasted with those benefiting the most from mining operations and other sources of local economic inequality, there exists uncertainty about where the Yandera prospect is headed and a growing discontent with Ramu Nickel's disdain for the general population of 'landowners', in addition to a shared sense among Papua New Guineans that they are being ripped off by foreigners and corrupt politicians. Ramu Nickel has paid relatively little in benefits and compensation to the community in relation to both its corporate profits and benefits and payments accorded to key middlemen.

Seeing the landowners' discontent as a political opportunity, Governor Peter Yama made a rare public appearance, declaring that he wanted Ramu Nickel investigated. Nothing came of this during the political turmoil over Peter O'Neill's alleged corruption and his recent stepping down as prime minister. However, when the even more recent toxic spill into the ocean at the Basamuk refinery caused major outrage, Governor Yama called for a shutdown—possibly a permanent shutdown—of Ramu Nickel. While many expected this would rattle the Chinese administrators at MCC, MCC simply claimed it had cleaned up the mess and paid for any damage 
in a strongly worded article in the Papua New Guinea Post-Courier. Unsurprisingly, The Boys said little about the poor royalty payments at Ramu Nickel and even the toxic spill, being leery of upsetting the powers that be at Ramu Nickel or Yandera and losing their jobs and incomes. ${ }^{5}$

While there is no open class war, there are plentiful signs that most Gende are angry about extreme differences in individual living conditions and wellbeing. Looking at gender in/equalities and generational differences, even rural-urban inequalities, is no longer sufficient. Relations of production and class differences_-be they defined as such or as a national proletariat and labour aristocracy (see Filer, this volume) — must be added to the intersectional equation, particularly when land and other forms of wealth are ending up in the hands of only some people.

\section{References}

Aufenanger, H. (1979). The Gende of Central New Guinea: Of the life and thought of a tribe in the Bismarck Ranges, Papua New Guinea (P. W. Holzknecht, Trans.). Oral History, $7(8 \& 9)$. Boroko, Papua New Guinea: Institute of Papua New Guinea Studies.

Bainton, N. (2008). Men of kastom and the customs of men: Status, legitimacy and persistent values in Lihir, Papua New Guinea. The Australian Journal of Anthropology, 19(2), 194-212.

Bainton, N. \& Banks, G. (2018). Land and access: A framework for analysing mining, migration and development in Melanesia. Sustainable Development, 26(5), 450-460.

Dickerson-Putman, J. \& Zimmer-Tamakoshi, L. (Eds). (1994). Introduction: Women, development and stratification in the Pacific. Urban Anthropology, 23(1), 1-11.

Faithorn, E. (1976). Women as persons: Aspects of female life and male-female relations among the Kafe. In P. Brown \& G. Buchbinder (Eds), Man and woman in the New Guinea Highlands (pp. 86-95). Washington, DC: American Anthropological Association.

Filer, C. (1985). What is this thing called 'brideprice'? Mankind, 15(2), 163-183.

5 On Facebook, The Boys have been openly critical of Yama's claim that he funded 100 scholarships for Madang Province youth to attend school in the Philippines. They and other suspicious Gende demand to know the names, districts and sex of those ' 100 ' students. 
Goodale, J. C. (1971). Tiwi wives: A study of the women of Melville Island. Seattle, WA: University of Washington Press.

Goodale, J. C. (1983). Siblings as spouses: The reproduction and replacement of Kaulong Society. In M. Marshall (Ed.), Siblingship in Oceania: Studies of the meaning of kin relations (pp. 275-305). Lanham, MD: University Press of America.

Hughes, I. (1977). New Guinea stone age trade: The geography and ecology of traffic in the interior (Terra Australis Vol. 3). Canberra, ACT: Research School of Pacific Studies, The Australian National University.

Kituai, A. (n.d.). 'From over the Blue Mountain range came the white men': Impact of the Divine Word missionaries in Gende (Bundi) 1932-1965. (Unpublished manuscript in author's possession.)

Macintyre, M. (1998). The persistence of inequality: Women in Papua New Guinea since independence. In L. Zimmer-Tamakoshi (Ed.), Modern Papua New Guinea (pp. 211-230). Kirksville, MO: Thomas Jefferson University Press.

Martin, K. (2013). The death of the big men and the rise of the big shots: Custom and conflict in East New Britain. New York, NY: Berghahn.

Morauta, L. (1979, September). Rural-urban exchanges and the analysis of Papua New Guinea's towns. Paper presented at the Sociological Association of Aotearoa (New Zealand) Conference, Canberra, ACT.

Morauta, L. (1981a). Mobility patterns in Papua New Guinea: Social factors as explanatory variables. In G.W. Jones \& H. V. Richter (Eds), Population mobility and development: Southeast Asia and the Pacific (pp. 205-228). Canberra, ACT: The Australian National University.

Morauta, L. (1981b, September). Redistribution within the village: Can we rely on it? Paper presented at the Fourteenth Waigani Seminar, University of Papua New Guinea, Port Moresby.

Morauta, L. \& Ryan, D. (1982). From temporary to permanent townsmen: Migrants from the Malalaua district, Papua New Guinea. Oceania, 53(1), 39-55.

Pickles, A. J. (2019). Money games: Gambling in a Papua New Guinea town. New York, NY: Berghahn.

Rosi, P. \& Zimmer-Tamakoshi, L. (1993). Love and marriage among the educated elite in Port Moresby. In R. Marksbury (Ed.), The business of marriage: Transformations in Oceanic matrimony (pp. 175-204). Pittsburgh, PA: University of Pittsburgh Press. 
Ryan, D. (1968). The Migrants. New Guinea, 2(4), 60-66.

Sexton, L. (1982). Wok meri: A woman's saving and exchange system in highland New Guinea, Oceania, 52(3), 167-198.

Sexton, L. (1986). Mothers of money, daughters of coffee: The wok meri movement. Ann Arbor, MI: University of Michigan Press.

Warry, W. (1986). Kafaina: Female wealth and power in Chimbu, Papua New Guinea. Oceania, 57(1), 4-21.

Weiner, A. B. (1976). Women of value, men of renown: New perspectives in Trobriand exchange. Austin, TX: University of Texas Press.

Z'graggen, J. A. (1975). Languages of the Madang District, Papua New Guinea. Canberra, ACT: Australian National University Press.

Zimmer, L. J. (1984, November). Pigs, money, migrants or men? Identity crisis in the Highlands of PNG. Paper presented at the 83rd Annual American Anthropological Association, Denver.

Zimmer, L. J. (1985). The losing game: Exchange, migration and inequality among the Gende people of Papua New Guinea (Unpublished doctoral thesis). Bryn Mawr College, Pennsylvania.

Zimmer, L. J. (1986). Card-playing among the Gende: A system for keeping money and social relationships 'alive'. Oceania, 56(4), 245-63.

Zimmer, L. J. (1987). Playing at being men. Oceania, 58(1), 22-37.

Zimmer, L. J. (1990a). Conflict and violence in Gende society: Older persons as victims, trouble-makers and perpetrators. Pacific Studies, 13(3), 205-224.

Zimmer, L. J. (1990b). When tomorrow comes: Future opportunities and current investment patterns in an area of high outmigration. In J. Connell (Ed.), Migration and development in the South Pacific (pp. 82-96). Canberra, ACT: Australian National University Press.

Zimmer-Tamakoshi, L. (1993a). Bachelors, spinsters and 'pamuk meris'. In R. Marksbury (Ed.), The business of marriage: Transformations in Oceanic matrimony (pp. 83-104). Pittsburgh, PA: University of Pittsburgh Press.

Zimmer-Tamakoshi, L. (1993b). Nationalism and sexuality in Papua New Guinea. Pacific Studies, 16(4), 20-48. 
Zimmer-Tamakoshi, L. (1996a). Role models for contemporary Gende women. In H. Levine \& A. Ploeg (Eds), Work in progress: Essays in New Guinea Highlands ethnography in honour of Paula Brown Glick (pp. 317-341). Germany: Peter Lang.

Zimmer-Tamakoshi, L. (1996b). The women at Kobum Spice Company: Tensions in a local age stratification system and the undermining of local development. Pacific Studies, 19(4), 71-98.

Zimmer-Tamakoshi, L. (1997a). Empowered women. In W. Donner \& J. Flanagan (Eds), Social organization and cultural Aesthetics: Essays in honor of William $H$. Davenport (pp. 45-60). Philadelphia, PA: University of Pennsylvania Press.

Zimmer-Tamakoshi, L. (1997b). The last big man: Development and men's discontents in the Papua New Guinea Highlands. Oceania, 68(2), 107-122.

Zimmer-Tamakoshi, L. (1997c). When land has a price: Ancestral gerrymandering and the resolution of land conflicts at Kurumbukare. Anthropological Forum, 7(4), 649-666.

Zimmer-Tamakoshi, L. (1998). Women in town: Housewives, homemakers and household managers. In L. Zimmer-Tamakoshi (Ed.), Modern Papua New Guinea (pp. 195-210). Kirksville, MO: Thomas Jefferson University Press.

Zimmer-Tamakoshi, L. (2001). Development and ancestral gerrymandering: David Schneider in Papua New Guinea. In R. Feinberg \& M. Ottenheimer (Eds), The cultural analysis of kinship: The legacy of David Schneider and its implications for anthropological relativism (pp. 187-203). Urbana, IL: University of Illinois Press.

Zimmer-Tamakoshi, L. (2006, February). Uncertain futures, uncertain pasts. Paper presented in working session on Mine Closure in the Pacific: Past Experiences and Anticipated Futures at the annual meeting of the Association of Social Anthropology in Oceania, San Diego.

Zimmer-Tamakoshi, L. (2007). Gende land management practices and conflicts over land: A patrilineal case. In R. J. May (Ed.), Land management and conflict minimisation projects: Review of the historical context of current land management and conflict management situations in the Pacific (pp. 59-68). Fiji: Pacific Islands Forum Secretariat.

Zimmer-Tamakoshi, L. (2008). It's not about women only. In L. ZimmerTamakoshi \& J. Dickerson-Putman (Eds), Pulling the right threads: The ethnographic life and legacy of Jane C. Goodale (pp. 56-76). Urbana, IL: University of Illinois Press. 
Zimmer-Tamakoshi, L. (2012). Troubled masculinities and gender violence in Melanesia. In M. Jolly, C. Stewart \& C. Brewer (Eds), Engendering violence in Papua New Guinea (pp. 57-81). Canberra, ACT: ANU E Press, doi.org/ 10.22459/EVPNG.07.2012.02

Zimmer-Tamakoshi, L. (2014a). Natural or unnatural partners? Inequality and the Gende's relations with mining companies. In P. D’Arcy, P. Matbob \& L. Crowl (Eds), Pacific-Asia partnerships in resource development (pp. 86-101). Madang, Papua New Guinea: Divine Word University Press.

Zimmer-Tamakoshi, L. (2014b). 'Our good work', or 'the Devil's work'? Inequality, exchange and card playing among the Gende. Oceania, 84(3), $222-238$.

Zimmer-Tamakoshi, L. (2016). Inequality and changing masculinities among the Gende in Papua New Guinea: The 'good', the 'bad', and the 'very bad'. The Asia Pacific Journal of Anthropology, 17(3-4), 250-267.

Zimmer-Tamakoshi, L. (2018). Fieldwork interrupted: The politics of fieldwork in Papua New Guinea. In L. Zimmer-Tamakoshi (Ed.), First fieldwork: Pacific Anthropology, 1960-1985. Honolulu, HI: University of Hawai'i Press.

Zimmer-Tamakoshi, L. \& Dickerson-Putman, J. (Eds). (2008). Pulling the right threads: The ethnographic life and legacy of Jane C. Goodale. Urbana, IL: University of Illinois Press. 
This text is taken from Unequal Lives: Gender, Race and Class in the Western Pacific, edited by Nicholas A. Bainton, Debra McDougall, Kalissa Alexeyeff and John Cox, published 2021 by ANU Press, The Australian National University, Canberra, Australia.

doi.org/10.22459/UE.2020.11 